İbrahim DAĞ $\breve{G}^{*}$

\author{
ULUSLARARASI EĞITTIM VE TARIH \\ ARAŞTIRMALARI DERGİSI \\ (ETA JOURNAL) \\ INTERNATIONAL JOURNAL OF EDUCATION AND \\ HISTORY RESEARCH
}

Yıl: 1, Sayı: 1, Aralık 2019, s. 40-51.

\title{
TÜRKLERIN ANAYURDU ÖTÜKEN
}

\section{ÖZET}

Ötüken'i etimolojik kökeni, coğrafi konumu, tarihsel ve dini başlıklar altında toplayan bu çalışmada, bugün ki Zavhan-Aymak sınırları içerisindeki Ötüken'i tarihsel ve dinî süreçlerde değiş̧imi dikkatlere sunulmuştur. Zavhan Aymak’taki Otgon Tenger Dağının vadisi ve Karakurum'a kadar ulaşan geniş bir coğrafyayı anlatmaktadır. Etimolojik kökeninin ayrımı üzerinde durulmuş bu kelimelerin ana yapısına bakılmaya gayret edilmiştir.

Hunlar, Göktürkler ve Uygurlar dönemindeki tarihsel süreçte Ötüken'in konumu dikkatlere sunulmuş olup, dinî bir kült hâline gelen coğrafya aktarılmaya çalışılmıştır. Kitabeler açısından önemi ve Türk tarihine mirası da ayrıca ele alınmaktadır. 1200 yıllık Türk yurdunun tarihi açıdan önemi ve ilk yurt Ergenekon'dan geliş de aktarılmaya çalışılmaktadır.

Anahtar Kelimeler: Ötüken, Türkler, Anayurt, Göktürkler, Türk Kültürü.

\section{TURK'S HOMELAND OTUKEN}

ABSTRACT

In this study, which gathers Ötüken under the titles of its etymological origin, geographical location, historical and Religious, the changes of Otuken in historical and religious processes within the boundaries of Zavkhan Aimag today have been brought to attention. The waley of the Otgon Tenger Mountain in Zavkhan Aimag describes a wide geograpy Reaching Karakurum. The distinction of its etymological origin has been emphasized and the main structure of these words has been tried to be looked at.

* Yüksek Lisans Öğrencisi, Süleyman Demirel Üniversitesi, Sosyal Bilimler Enstitüsü, Tarih Anabilim Dal, ibrahimdag.90038@gmail.com. 
During the historical period of the Huns, Gokturks and Uyghurs Otuken's position was brought to attention and the geography that became a religious cult was tried to be transferred. Its importance in terms of inscriptions and its heritage in Turkish history are also discussed. The importance of 1200 year-old Turk's Homeland for Turkish history and the first homeland is being tried to be transferred out of Ergenekon.

Keywords: Otuken, Turks, Homeland, Gokturks, Turkish Culture.

\section{GíRiş}

Türklerin ilk yurdu olarak bütün kaynaklar Ergenekon'u göstermektedir. Ergenekon Efsanesi, Türklerin demirden dağı eriterek çıktığı MÖ binli yıllara ${ }^{1}$ dayandırılmaktadır. Jean Paul Roux, bu efsaneyi İran tarihçisi Reşidüddin'in Moğollara yâd ettiğini vurgulamıştır. Bunun sebebi İran'da Türkleri de Reşidüddin'in, Moğol olarak aktarmasıdır ki Roux da bu konuya açıklık getirmektedir. Roux ayrıca bu efsanenin Altaylarda demircilik yapan Juan-Juanların içine yerleşen Tu-Kiu'ların bir anısı olduğunu açıklamıştır. ${ }^{2} \mathrm{Bu}$ durum Cengiz Han döneminde aktarılmış olmalı ki gizli tarihlerinde de yer bulmuştur. Bu efsane o kaynaklarda bir kişiye yâd etmiş olmasına karşın Roux'a göre bir ulusundur. ${ }^{3}$ Bahaeddin Ögel ise bu durumu Cengiz Han çağında Göktürklerin Türeyiş Efsanesi'nin dejenere edilerek kullanıldığı şeklinde açıklamaktadır. ${ }^{4}$ Diğer taraftan "Kök Börü Efsanesi” olarak bilinen bu sözlü geleneğin Moğol İmparatorluğu zamanında kaleme alınmış olması, Moğollara atfedilmesine sebep olmuştur. ${ }^{5}$ Sonuç olarak Ergenekon'dan çıkan bu ulusun Onon (Orhon ya da Orhun) ve Kerülen bölgesine ${ }^{6}$ yerleştikleri bilinmektedir. Ayrıca Hiung-nu'lardan (Hunlar) Teoman ve Mete'nin MÖ 210-174 yılları arasında Kerülen bölgesinde kavimleri bir çatı altında toplamakta olduğunu görmekteyiz. ${ }^{7}$ Bu durumda Hunların devamı olduğunu söyleyen Göktürklerin de Ergenekon çıkış kaynağ 1 tespit edilmektedir. Öyle ki Ergenekon Göktürklerin inancında yer etmiş ve demirci olan Göktürklerin, Ergenekon'da demirden dağı eriterek çıkmaları hadisesi kültürel bir miras hâlinde nesilden nesile aktarılmıştır.

$\mathrm{Bu}$ sayede Türkler, Kerülen ve Onon bölgesine yerleşerek 1200 y1l boyunca devam edecek bir anavatan oluşturmuşlar ve devletlerine başkentlik edecek Ötüken'i kurmuşlardır. Ötüken'in doğusundaki Ergenekon Vadisi'ne bu yüzden Türkler arasında kutsal sayılmıştır. Güneşin doğudan doğuşu ve kendilerinin doğudan gelişini bütünleştirmişler ve kutsal saymışlardır. Zaman içerisinde Ötüken vadisine geliş bu şekilde cereyan etmiştirI. Ötüken'in Etimolojik Kökeni ve Coğrafyası

\footnotetext{
${ }^{1}$ J. Paul Roux, Moğol İmparatorluğu Tarihi, (çev. Aykut Kazancıgil), Kabalcı Yayınevi, İstanbul 2001, s. 65 .

${ }^{2}$ Roux, a.g.e., s. 65.

${ }^{3}$ Roux, a.g.e., s. 65.

${ }^{4}$ Bahaeddin Ögel, Türk Mitolojisi, MEB Yayınları, C.1, İstanbul 1993, s. 37.

5 Özgür Türker, Nefesten Taşa, Taştan Kağıda: Türkler ve Moğollarda Tarih Yazıcılığı, Türkiye Âlim Kitapları, Saarbrücken 2014, s. 18.

${ }^{6}$ Roux, a.g.e., s. 65.

7 J. Paul Roux, Orta Asya Tarih Ve Uygarlık, (çev. Lale Arslan), Kabalcı Yayınevi, İstanbul 2006, s. 89.
} 


\section{I.I. Etimolojik Köken}

Ötüken'in Şine Usu ve Terhin yazıtlarında As Öyüz ve Kan Iduk kelimelerinin "ötü” kökünden fiilden ad yapan $+\mathrm{G}$ ve addan ad yapan $+k A n$ ekiyle kurulmuş olması muhtemeldir. ${ }^{8}$ Bu kelimeyle Otgon Tenger Dağı'nın zirvesi başta olmak üzere geniş bir yaylak ifade edilmeye çalışılmıştır. ${ }^{9}$ Ayrıca Moğolcada Etugen, Otogen ya da Itugen ifadesinde de rastlanılmaktadır. ${ }^{10}$ Günümüz Türkçesinde Latin alfabesindeki yumuşamayla "Ötükän"11 iken dilimize Ötüken olarak çevrilmiştir.

Bir diğer unvan ile Göktürk Kağanlığında "yış"12 unvanında kullanılmış, "yer-suv" ya da "yer-sub"13 olarak bilinmektedir. Bunların yanı sıra kutsal ya da mukaddes olarak bilinen "Iduk"14 unvanını da almıştır. Kaşgarlı Mahmud ise eserinde "Iduk" kelimesini serbest bırakılan anlamında tasvir etmiştir. ${ }^{15}$

Birçok araştırmacı ve etimoloji çalışanları farklı görüşler iddia etse de geniş bir coğrafyaya yayılan Ötüken'i dağlar, yaylaklar, ırmaklar ve ormanlarla sinıllandırmamak gerekir. Bu bağlamda belirli bir yer adı olarak görülmemesi gerekmektedir. Bu veriler sonucunda kağanlık merkezi ve başkent Ötüken'i bir alana yayılmış geniş bir coğrafya olarak kabul edebiliriz. Doğu Türkistan'da Kan-Su Irmağı'ndan başlayıp Moğolistan'ın içlerine kadar uzanan Moğol İmparatorluğu döneminde başkentlik etmiş Karakurum dolaylarına da ulaşan bir coğrafya şeklinde tasvir etsek daha doğru olacaktır. Bunun yanı sıra Moğolistan'ın bugün dahi Tarım ve Hayvancılık ekonomisini şekillendiren Orhun Irmağı bir uçtan diğer uca Ötüken'i sarmaktadır. ${ }^{16}$ Bu sebeple bu coğrafyadan tarih boyunca yararlanıldığı aşikârdır.

\section{I.2. Coğrafi Konum}

Ötüken coğrafyasına dair birkaç iddia ileri sürülmektedir. Bahaeddin Ögel; "Baykal Gölü'nün güneybatısında, yüksek dağlar ve Orhun, Tamır ırmakları ile çevrili, müdafaası kolay, fakat etrafi akınlar yapmaya elverişli mevkii de, (47. enlem - 101. boylam) iklimi mutedil ve otlağı bol bir yer olan Ötüken yaylası" ${ }^{17}$ diye tasvir etmiştir.

J. Schubert'in İbrahim Kafesoğlu tarafindan tercüme edilen "Ural-Altaische Jahrbücher" dergisindeki "Zum Begriff Und Zur Lage De Ötükan” başlıklı makalesinde Ötüken'in konumu 47. enlem ve 98 . boylam olarak belirtilmiştir. ${ }^{18}$ Yanı sıra Asya Hunlarında Ongin Irmağ 1 üzerindeki Karakum ile Ordos bölgesi arasında ${ }^{19}$ devletin ağırlık merkezini Ötüken olarak tasvir etmiştir.

\footnotetext{
${ }^{8}$ Erhan Aydın, "Ötüken Adı ve Yeri Üzerine Düşünceler", Turkish Studies İnternational Periodical For The Languages, Literature And History of Turkish or Turkic, C. 2, S. 4, 2007, s. 1262.

${ }^{9}$ Aydın, a.g.m., s. 1262.

${ }^{10}$ a.g.m., s. 1262 .

${ }^{11}$ Muharrem Ergin, Orhun Abideleri, Boğaziçi Yayınları, İstanbul 1978, s. 65. açkl. Kül Tigin Yazıtı, Gy, str.3.

${ }_{12}^{12}$ Ergin, a.g.e., s. 65 açkl. Kül Tigin Yazıtı, Gy, str.4.

13 a.g.e., s. 78 açkl. Bilge Kağan Yazıtı, Dy, str. 10.

${ }_{14}^{14}$ a.g.e., s. 68 açkl. Kül Tigin Yazıtı, Dy, str. 10-11.

${ }^{15}$ Kaşgarlı Mahmud, Divanû Lügat-it-Türk, C.1, (çev. Besim Atalay), TDK Yayınları, Ankara 2006, s. 65; J. Paul Roux, Türklerin Ve Moğolların Eski Dini, (çev. Aykut Kazancıgil), Kabalcı Yayınevi, İstanbul 2002, s. 139.

${ }^{16}$ Saadettin Gömeç, "Kök Türkçe Yazıtlarda Geçen Göller ve Nehirler", Tarih Araştırmaları Dergisi, C. XXVII, S. 44, Ankara 2008, s. 12.

${ }^{17}$ İbrahim Kafesoğlu, Türk Milli Kültürü, Ötüken Yayınevi, İstanbul 2015, s. 110.

${ }^{18}$ Kafesoğlu, a.g.e., s. 110.

${ }^{19}$ a.g.e., s. 56.
}

ULUSLARARASI EĞİTIM VE TARIH ARAŞTIRMALARI DERGİSI

(ETA JOURNAL)

INTERNATIONAL JOURNAL OF EDUCATION AND HISTORY RESEARCH

Yıl: 1, Sayı: 1, Aralık 2019, s.40-51. 
Türkçenin tarihî kaynaklarının en önemlilerinden birisi olan Divanü Lûgat-it-Türk’te Kaşgarlı Mahmud çok geniş bir yer tespiti yapmakta ve ne yazık ki bu yer tespiti çok fazla işe yaramamaktadır: "Ötüken, Tatar çöllerinde, Uygur ülkesine yakın bir yerin adıdır." ${ }^{20}$ Çöllerden kastı büyük ihtimalle Gobi ve Karakum çölü olsa gerek ki yer hakkında tek ayrıntılı bilgiyi böyle nakletmektedir.

Annemarie Von Gabain ise Ötüken'in coğrafi konumu hakkında; “Cenuptan Hangay dağı, şimalden de Tangnu-Ola ile sarılmış olan Ötüken yaylaları, tabî̀ ve yüksek bir kale vaziyetinde idi" ${ }^{\prime 21}$ yorumunu yaparak yer tayini konusunda dağlarla çevrili zapt edilmesi zor olan ve yüksekte bulunan bir mevkii olarak gösteriyor.

Göktürk Kitabelerinde ise Ötüken'i terk etmemek gerektiği ve kutsallığı üzerine durulurken yer tayin edilmemektedir. Yenisey Yazıtlarında yer belirtisi biraz daha belli ve açıktır. Terhin Yazıtı'nda; “yaylam Ötüken'in kuzey (yamaçlarının) batı ucu, Tez (ırmağı) başı, doğusu Kanyuy ve Künüy (trmaklarl)"22 diyerek açık bir yer tayini vurgusu yapılmaktadır.

Günümüzde ise tam olarak Bugünkü Moğolistan'ın Zavhan-Aymak sınırları içerisinde bulunan ve $4021 \mathrm{~m}$. yüksekliğindeki Otgon Tenger adlı volkanik dağın, Hangay dağ sırasının en yüksek bölümünü oluşturduğu bilinmektedir. ${ }^{23}$

\section{Tarihsel ve Dinî}

\section{1.Ötüken'in Tarihsel Kökleri}

\subsubsection{Hunlar Zamanında Ötüken}

Hun siyasi birliğinin kesin tarihini MÖ 4 . yüzyıla kadar takip etmekteyiz. ${ }^{24}$ Bu sebeple Ötüken'in kağanlığın ağırlık merkezi olarak tayin edilmesi bu dönemlere denk gelmektedir. Hunlara dair bu vesika MÖ $318^{\prime} \mathrm{e}^{25}$ tekabül etmektedir. Doğu Türkistan'daki Kan-Su Irmağı'ndan kuzeyde Karakum-Ordos bölgesine kadar uzanan yaylak ve kışlak olarak Hunlar tarafından kullanılmaktaydı. Teoman ve Mete'nin Kerülen bölgesinde MÖ 210 yıllarında Türk kavimlerini toplayışı da Ötüken'in kaç yıllarında kurulduğunun ipuçlarını bizlere verilmektedir. Ongin havalisi Kerülen ve Orhun ırmakları arasında büyük bir coğrafyaya yayılmış olarak görünmektedir. Bu sebeple Türk boyları bu coğrafya da yarı göçebe hâliyle yaşamlarını idame ettirmişlerdir. Çin'e kuzeyden sürekli saldırı hâlinde bulunan Hunların bu coğrafyada etkili olarak hareketliliğini de görebiliriz. Bu durumun geniş Türkistan coğrafyasında sorunlara da yol açmakta olduğunu varsayabiliriz. Genişleyen toprakların idaresi yönetime güçlük çıkartarak bölünmeye sebep olmaktadır. İkili teşkilat sistemi içerisinde devletin geniş sınırları hâkim olmayı zor kılarak, Çin'in propagandası ile birlikte devleti bölünmeye sevk etmiştir. Devletin batısını kontrol eden Çi-Çi ve devletin doğusunu yöneten Ho-Han-Yeh Çin'in propagandası neticesinde ayrılığa düşmüşlerdir. Ayrıca Hun prensleri de kendi içlerinde kavga hâlinde idiler. Netice itibarı ile MÖ 58-31 yıllarında Ho-Han-Yeh Çin himayesini istemesiyle Hun siyasi birliği ikiye ayrılmıştır. ${ }^{26}$ Çi-Çi batıya giderek Avrupa Hunlarını oluşturmuştu. Hunlardan sonra

\footnotetext{
${ }^{20}$ Aydin, a.g.m., s. 1263.

${ }^{21}$ Annemarie V. Gabain, "Köktürklerin Tarihine Bir Bakış”, Dil ve Tarih-Coğrafya Fakültesi Dergisi, S. 5, Ankara 1944 s. 687.

${ }^{22}$ Aydın, a.g.m., s. 1266; ayr. Terhin Yazıtı, By, str. 5.

23 a.g.m., s. 1266.

${ }^{24}$ Kafesoğlu, a.g.e., s. 59.

${ }^{25}$ Maria De Groot, "Die Hunnen Der Vorchristlichen Zeit”, Walter De Gruyter, H. 1, S. 0, Berlin 1921, s. $1-38$.

${ }^{26}$ Kafesoğlu, a.g.e., s. 64.
} 
(MS 300 ve 500 yılları arasında) Tabgaçlar kısa bir döneme tekâbül eden bir zaman zarfinda Ötüken'e yerleşmişler ve Juan-Juanlar da bu devlete katılmışlardır.

\subsubsection{Göktürkler Zamanında Ötüken}

Ötüken için bir diğer tarihsel süreç de Hunlardan ayrılan Juan-Juan devleti içerisinde ki Göktürkler dönemi ile başlamıştır. Şüphesiz ki Göktürkler, Ötüken'i yerleşik yaşama geçiş denemelerine konu ederek bunu bıraktıkları ve Türk tarihinin ilk yazılı kaynakları olarak bilinen yazıtlarında iyi bir konuma taşımışlardır. Juan-Juanlara karşı bir Töles ayaklanmasını bastıran Bumin Kağan, onlara denk olduğunu iddia ederek kağanlığın merkezini $552^{27}$ y1lında Ötüken’e taşımıştır.

Daha sonrasında Çin'in izlediği siyaset ve kağanların izledikleri yanlış politika sonucunda I. Göktürk Kağanlığı dağılmış ve Türk Töles boyları Çin'e vergi vererek bu bölgede yaşamaya devam etmişlerdi. ${ }^{28}$ I. Göktürk Kağanlığından kopan birçok boy varlıklarını idame ettirmek için Çin himayesini kabul etmek zorunda kalmışlardır.

630-680 yılları arasında Göktürklerin hanedan soyu olan "Aşina" boyundan Kutlug(İlteriş), Kağanlığı tekrar birleştirmek istedi. Kardeşi Kapgan da Çin'de dağınık hâlde yaşayan Türkleri Anavatan'a (Ötüken) çekmek istedi. ${ }^{29}$ Bu teşkilatı tayin etmek için elbette ki Ötüken'e sahip olmak gerekiyordu. Kutlug Göktürklerin ileri gelenlerini çağırırken I. Göktürk Kağanlığında ünlü bir devlet adamı ve kumandan olan Tonyukuk da onlara katıld1. ${ }^{30}$ Kutlug ile Tonyukuk Çogay'ın kuzey eteklerini yaylak ve Karakurum'u kışlak merkezi yaparak ${ }^{31} 681$ 'de Türk boylarını toplamaya başladılar. İlteriş'in ölümünden sonra Bilge Kağan ve Kül Tigin Kağanlık merkezi olan Ötüken'i toparlamış ve buradaki Göktürk Kitabelerini Türk milletine miras bırakmışlardı. Zaman içerisinde Bilge Kağan'ın ölümü ardından Göktürk Kağanlığı zayıflamış, daha sonra Uygurlar başa geçerek Ötüken'i başkent ilan etmişlerdir(745). ${ }^{32}$

\subsubsection{Uygurlar Zamanında Ötüken}

Uygurlar ilk olarak 5. yüzyılın ikinci devresinde siyasi birlik kurmuşlardı. ${ }^{33}$ Zaman içerisinde Göktürk Kağanlığının yerini alarak yükselmişler ve uygarlık anlayışı içerisinde başkent Ötüken'i geliştirmişlerdir. Uygurlar, Türk Töles boylarını Ötüken'de toplamış ve önemli kitabeler bırakarak anayurt Ötüken'e atıfta bulunmuşlardır. Ayrıca Uygur Yazıtları Maniheizm ve Budizm gibi dinleri de tanıtmak için yazılmıştır. Uygurca, Çince ve Soğdca yazılmış olan bu yazıtlar Türk tarihi ve edebiyatında da yer edinmiştir. Yalnız Uygur Devleti zaman içerisinde gücünü yitirerek Çin'in yıkıcı propagandasına zayıf düşmüştür.

Uygur halkı zaman içerisinde devlet adamlarının dirayetsizliği ve Çin'in baskıları neticesinde hızlı bir yıkılış sürecine girerek, 940'ta Kuzey Mançu'da kurulan Kitanların ve daha

\footnotetext{
${ }^{27}$ Bahaeddin Ögel, "Doğu Göktürkleri Hakkında Vesikalar Ve Notlar”, Belleten, C. XXI. , S. 81, Ankara 1957, s. 118.

${ }^{28}$ Ahmet Taşağıl, Gök-Türkler I-II-III, TTK, Ankara 2018, s. 287.

${ }^{29}$ Gabain, a.g.m, s. 689.

${ }^{30}$ Ergin, a.g.e., s. 95; açkl. Tonyukuk Kitabesi, Ky, Str. 5.

31 a.g.e., s. 95; açkl. Tonyukuk Kitabesi, Ky, Str. 7. Ayr. Bknz. Rene Giraud, "Göktürk İmparatorluğu İlteriş, Kapgan ve Bilge'nin Hükümdarlıkları”, Çev. İsmail Mangaltepe, CBÜ Sosyal Bilimler Dergisi, C. 9, S. 2, Manisa 2011, s. 729-736.

${ }^{32}$ Kafesoğlu, a.g.e., s. 124.

${ }^{33}$ Bahaeddin Ögel, “İlk Töles Boyları”, Belleten, C. XII, S. 48, Ankara 1948, s. 811-826. 
sonrasında ise 1028 'de Tangutların nüfuzu altına girdiler. Uygur Kağanlığı da böylece siyasi varlığını yitirerek yıkılmış oldu. ${ }^{34}$

Sonuç olarak Hunlardan başlayan 1200 yıllık tarihsel süreçte anayurt Ötüken Türk milletine başkentlik ederek bu zaman zarfında askeri ve siyasi yapısını korumuş oldu. Hayvancılık açısından geniş otlaklar sağlayan ve ticaret yolları üzerinde bulunan Ötüken, coğrafi konumu sayesinde Türk topluluklarının nüfuzunu geliştirmesini sağladı. Göktürk ve Uygur yazıtları ile tarih ve edebiyat alanında ilk örnekler verildi.

\section{2. Ötüken'in Dini Yapısı}

\subsection{1. "Iduk" (Mukaddes) Ötüken}

Ötüken Türkçede "Yer Tanrısı" ya da "Yer Tanrıçası" demektir. Çin kayıtlarında "P’oTeng-li" şeklinde geçmektedir. ${ }^{35}$ Türk ve Moğol mitolojisinde ise "Toprak Ana" olarak bilinmektedir. Kitabelerde "Yer sub" ya da Uygur yazıtlarında "Yer suv" hâliyle iki yerde mukaddes olarak zikredilmiştir; "Iduk Ötüken" ${ }^{36}$ ve "Tamıg Iduk Baş" ${ }^{37}$. Iduk daha önce de belirttiğimiz gibi Kaşgarlı'ya göre "serbest bırakılan" anlamına gelmektedir.

Kitabelerin yanı sıra Çin kaynaklarından da istifade eden P. Pelliot şu fikri ileri sürmüştür:

“Ceu-su'ya göre eski Türklerin üç büyük mukaddes yeri vardl: Birincisinde,

Türk Kağanı otururdu. Buraya Yu-Tu-Kın (Ötüken) derlerdi. İkinci ise Tajen Nehri yakınında olup, Göktürklerin kurban sundukları oland. Üçüncüsü ise, Ötüken dă̆ları üzerinde bir tepeydi. Tepe üzerinde ne bir ăgaç ne de bir ot biterdi. Işste burası Mukaddes Ötüken'dir. "38

$\mathrm{Bu}$ durum zaman içerisinde Moğol ve Altay inancı yerine de geçmiştir. Öyle ki Moğol Hükümdarı Cengiz Han Merkitleri yendikten sonra "Toprak Ana Etugen (Otogen ya da Itugen)" "39' in yardımı sayesinde yendiğini söyleyerek Ötüken'i Tanrı ve Ruh hâlinde gösteriyor. Bunun yanı sıra Marco Polo'nun seyahatnamesinde Moğolların içindeki bir Türk boyu olan Tatarlar arasında "Natıgay"40 adında bir Tanrının Etugen (Ötüken) adındaki eşinden bahsediliyor. Marco Polo'nun kastettiği bu Tatarların kuzeyde yaşadığı görülmektedir. Polo'nun bahsettiği efsanevi Natıgay ve eşi Tatarların hayatlarını kumanda eder, mahsulün bol olmasını sağlar ve hayvanlarını korurdu. Tatarlar da kurban vererek bu Tanrı ve Tanrıçayı kutsamaya çalışırlardı.

Sonuç olarak Göktürkler ve Uygurlardaki yazıtlar aracılığıyla Ötüken'in inanç noktasında da etkili olduğunu görüyoruz. Türk, Altay ve Moğol mitolojisine de bu anlamda etkisi olmuştur. Türklerde "Toprak Ana" iken Moğol etkisiyle "Tanrıça" olarak da anılmıştır.

\footnotetext{
${ }^{34}$ Kafesoğlu, a.g.e., s. 132.

${ }^{35}$ P.Wilhelm Schmidt, "Eski Türklerin Dini”, İÜEF Türk Dili ve Edebiyatı Dergisi, C. 13, S. 1, İstanbul 1964, s. 75.

${ }^{36}$ Ergin, a.g.e., s. 77; açkl. Bilge Kağan Yazıtı, I. Taş, Dy, str. 3, 23-24.

${ }^{37}$ a.g.e., s. 87; açkl. Bilge Kağan Yazıtı, I. Taş, Ky, str. 1 ve II. Taş, Dy, str. 29.

${ }^{38}$ Ali Öztürk, Ötüken Türk Kitabeleri, Ötüken Yayınevi, Ankara 1973, s. 121.

${ }^{39}$ Moğolların Gizli Tarihi, (çev. Ahmet Temir), TTK, Ankara 2016, s. 51.

${ }^{40}$ Marco Polo, Marco Polo Seyahatnamesi, Terc. 1001 Temel Eser, C. 2, İstanbul 1990, s. 217.
} 


\subsection{2. Ötüken'de Törenler ve Yer-Su Kültü}

\subsubsection{Dăg Kültü}

Eski Türklerde yer-su kültü içerisinde dağ kültü, orman kültü ve ırmak (su) kültü olarak Ötüken'de bazı dinî törenler yapılmaktaydı. Dağ kültü içerisinde Gök Tanrı inancıyla doğrudan alaka görülür. Hunlarda yeni Sİ-Şan veya San-Din-Şan sıra dağları ve Hundağı 'nda Çin ile yapılan antlaşmayı teyit etmek için kurban kesilirdi. ${ }^{41}$ Gök Tanrı'ya kurban yüksekçe dağlarda verilirdi. Türkistan'daki dağlara da bu sebeple mukaddes denilmesi ve kağan isimleri verilmesi kişilik ve kutsallık kazanmasına en büyük örnektir.

Göktürkler ise Ötüken'in 250 km batısındaki "kuttag"42 denilen bir dağı mukaddes bilip, Gök Tanrı ve mahsulün iyi olması için Toprak Anaya kurban sunuyorlardı. Ayinlerini ayrıca Tamır Dağı eteklerinde ve kağanlık merkezinde kağanın soyuna kurban keserek onamış oluyorlardı. Göktürkler, Mukaddes Ötüken'in ot vermeyen dağlarını Tanrı'nın mekânı olarak görmüş ve toplanan kurultaylarda kurbanlarını orada Gök Tanrı'ya sunmuşlardır.

Daha sonra Uygurlar da Ötüken'i mukaddes bilerek Otgon Tenger Dağı zirvesinden başlayarak Ötüken dağlarını kutsal saymışlar ve ayinlerini bu dağlarda yapmışlardır. Gök Tanrı ve Toprak Ana olan Ötüken'e ve yanı sıra atalara at ve koyun kurban etmişlerdir. Uygurlardaki "Kutlu Dağ Efsanesi”“43 de yine Ötüken için söylenmiştir. Altay halklarında genellikle cereyan eden bu kült yine bu halkların inancını büyük ölçüde oluşturmaktadır. Altay ve Tanrı Dağları da bu kıssada hep kutsal sayılmıştır. Günümüzde de bu dağ kültünün Anadolu'ya kadar ulaşmış olduğunu görmekteyiz. ${ }^{44}$

\subsubsection{Orman ve Ăgaç Kültü}

Orman ve ağaç kültü içerisinde ise Kutsal Ötüken dağı ormanlarla kaplıdır ve "Ötüken yış" (Ötüken ormanı), Göktürkler ve Uygurlarca kutsal var sayılır. ${ }^{45}$ Bu korulukta kutsal ayin olarak kayın ăgacı dikilmekte ve kurban sunulmaktadır. ${ }^{46}$

Eberhard eserinde Türklerin göğe, yere ve kağanın soyuna kurban kestiklerini, kayın ağaçları diktiklerini ve bunlardan "tanrılık" ve "kutlu orman" 47 meydana geldiğini dile getirmektedir. Ayrıca Bahaeddin Ögel de "Türklerde kutsal Ötüken orman ve dağlarının yüksek olduğunu sayarsak" diyerek kutsallığını ifade etmektedir. ${ }^{48}$ Doğa ile özdeşleşen eski Türkler hükümdarlarının da 1şık veya hayvan olabilen göksel bir tanrı ile su, ağaç ya da kutsal bir hayvan olabilen yer tanrısından doğduğuna inanırlardı. ${ }^{49} \mathrm{Bu}$ doğrultuda dikilen her ağacın hükümdar soyunu beslediğine inanırlardı. Hunlardan başlayan bu olgu sonraki dönemlerde Tabgaçlarda da devam etmektedir. Tabgaçlar, ilk ve sonbaharlarda atalara kurban sunarlar, tapınak makamındaki taş ev içinde kesilen kurbandan sonra civara yine kayın ağaçları

\footnotetext{
${ }^{41}$ Ünver Günay-Harun Güngör, Türklerin Dini Tarihi, Rağbet Yayınları, İstanbul 2007, s. 73.

42 a.g.e., s. 73.

43 İbrahim Kafesoğlu, Eski Türk Dini, Kültür Bak. Yay., Ankara 1980, s. 27.

44 Türklerdeki dağ kültürü ve Anadolu'daki izleri hakkında bkz. Onur Köse, "Türk Kültüründe Dağ ve Düzgün Baba Dağı”, Genel Türk Tarihi Araştırmaları Dergisi (GTTAD), C. 1, S. 1, (Ocak 2019), s. 13-24.

${ }^{45}$ Günay-Güngör, a.g.e., s. 75.

${ }^{46}$ a.g.e., s. 75.

${ }^{47}$ Wolfrem Eberhard, Çin'in Şimal Komşuları, çev. Nimet Uluğtuğ, TTK, Ankara 1996, s. 80.

${ }^{48}$ Bahaeddin Ögel, Türk Mitolojisi II, Milli Eğitim Bas., İstanbul 1971, s. 266.

${ }^{49}$ Roux, a.g.e., s. 61.
} 
dikerlerdi. ${ }^{50}$ Kutlu orman oluşturulmasına yola açan bu inanç kültürü içinde ağaç ve ormanların önemi böylelikle ortaya çıkmaktadır. Göktürkler ve Uygurlar da bu inancı kağanlık merkezi çevresine ağaçlar dikerek dinî bir tören şeklinde devam ettirmiş̧lerdir. Kağanlıkta toplanan toy sonrası ya da törenlerde ağaçlık ve ormanlara önem vermişlerdir.

Manevi kuvvet olarak tasavvur edilen bu kült, diğer mitolojilerde görüldüğü gibi tanr1 noktasında değil inanç kıssasında tasavvur edilmiştir. Orman ve ağaç kültüne önem bu sayede ortaya çıkmaktadır.

\subsubsection{Irmak (Su) Kültü}

Irmak kültünde kitabelerde de rastlanıldığı üzere "Tamıg Iduk Baş"51 ifadesiyle Tamır Irmağı'nın doğduğu yerin kutsal olduğunu görüyoruz. Göktürkler ve Uygurlar Tamır Irmağı'na çeşitli ayinlerle kurban keserek Yer-sub ve Gök Tanrıya sunuyorlardı. Ötüken'in Orhun ve Selenga'yla çevrili olduğunu düşünürsek doğal bir korunağın yanı sıra bunun bir kutsallığa da işaret ettiğini varsayabiliriz. Ongin ve Kerülen ırmakları da buna örnek teşkil eden önemli irmaklardandır.

Hunlarda ise Güneş ve Ay'ın kutsallığının yanı sıra Kan-Su Irmağı'ndaki ayinlerde kurban kesilmesi de yine ırmak kültüne önemli bir örnektir. Özellikle Çin hükümdarlarıyla yapılan antlaşmalardan sonra karşılıklı bir heyet oluşturularak, Kan-Su Irmağı'nda kurban kesilip ayin ve tören gerçekleştirerek antlaşmayı kutsal bir boyuta taşımışlardır. Bunun yanı sıra Ötüken havalisi, Ongin Irmağı üzerindeki Karakum ile Ordos bölgesi de bu irmakların kutsallığını ve önemini ispat etmektedir. Bilge Kağan Yazıtı'nda “Tanrı, Umay*, Mukaddes Yer-Su düşman üzerine duman çöktürdü",52 diyerek yer ve su kültlerinin doğal korunak avantajlarını ve kutsallığını vurgulamaktadır.

Irmak kültü ayrıca yaşam kaynağıdır. Geçimini hayvancılıkla sağlayan eski Türkler otlak ve ırmak çevresinde yaylak kurmaya önem göstermişlerdir. Bu kültün doğa figürü olmasının yanı sıra kutsallığına delalet eden nokta insanların ellerini bile bu nehirlerde yıkamakta imtina etmeleridir.

\section{SONUÇ}

Ergenekon'dan çıkan eski Türklerin Ötüken'i yurt edinerek 1200 yıllık tarihi süreci başlatmaları bu çalışmamızın konusunu oluşturmaktadır. Moğollara yâd edilmiş bir destanın aslında Türklerin anekdotları olduğu kabul görmüştür. İranlı müverrihlerin o dönemin siyasi konjonktüründe Türkleri Moğollarla özdeşleştirmesi buna neden olmuştur. Bu bağlamda Göktürklerden Kök Börü Efsanesi'nin aslında eski Türkler tarafindan kutsal sayılan ilk yurdun izlerini taşıdığg ve daha sonrasında Moğollar tarafindan da bu geleneğin sürdürüldüğü sonucuna varılmıştır.

Ayrıca Ötüken'in etimolojik kökeninin As Ögüz ve Kan Iduk kelimelerinden meydana gelmesi ve Terhin-Şine Usu yazıtların da böyle yer alması üzerinde durulmuştur. Coğrafi konumun tayin edilmesinde de yine yazıtlardan yola çıkılarak önemli bilim insanlarının görüşlerinden istifade edilmiştir.

Tarihsel süreç içerisinde Hunlar tarafından MÖ 200 yıllarından itibaren yurt edinilen başkentin Göktürkler zamanında daha da önem kazandığı ve bunun yanında dinî açıdan da

\footnotetext{
${ }^{50}$ Kafesoğlu, a.g.e., s. 290.

${ }^{51}$ Ergin, a.g.e., s. 87; açkl. Bilge Kağan Yazıtı, Taş 1, Ky, str. 1 ve Taş 2, Dy, str. 29.

* Umay: Eski Türklerde çocukları koruyan iyilik tanrıçası.

52 Öztürk, a.g.e., s. 120; Bilge Kağan Yazıtı, By, str. 3.
} 
kutsal sayıldığı üzerinde durulmuştur. Göktürkleri yıkarak onların devamı olan Uygurların da Ötüken coğrafyasına, kazandırdığı tarihsel önem dikkate alınmıştır.

Zaman içerisinde kutsal bir hâle bürünen coğrafyanın dine etkisi ve toprak ana anlamında olacak bir ruha dönüşünün de üzerinde durulmuştur. Bu durumun Moğollar döneminde hız kazanarak "Yer Tanrıçası" hâline gelen Ötüken'i de bir inanç merkezi konumuna getirmiştir. Kutsal Ötüken'e yapılan ayinler ve yer su kültü içerisindeki yeri de dikkate alınmaktadır. Kitabelerdeki öneminden yola çıkılarak Türk tarihi bakımından ne denli önemli bir unsur oluşturduğu incelenmiştir. Dağ kültü, orman kültü ve ırmak (su) kültü açısından yeri ve konumu da tayin edilmeye çalış1lmıştır. Sonuç olarak Ötüken'i tarihsel, dinî ve kültür olarak incelemeye alan bu çalışmada, Türk toplumlarında Ötüken'in yeri ve önemi aktarılmak istenmiştir.

\section{KAYNAKÇA}

AYDIN, Erhan, "Ötüken Adı ve Yeri Üzerine Düşünceler", Turkish Studies International Periodical For The Languages, Literature And History Of Turkish Or Turkic, C. 2, S. 4, 2007, s. 1263-1270.

DE GROOT, Maria, "Die Hunnen Der Vorchristlichen Zeit", Walter De Gruyter, H. 1, S. 0, Berlin 1921, s. 1-38.

EBERHARD, Wolfrem, Çin'in Şimal Komşuları, (çev. Nimet Uluğtuğ), T.T.K, Ankara 1996.

ERGIN, Muharrem, Orhun Abideleri, Boğaziçi Yayınları, İstanbul 1978.

GABAIIN, Annemarie, "Köktürklerin Tarihine Bir Bakış", Dil ve Tarih-Coğrafya Fakültesi Dergisi, B. 2, S. 5, Ankara 1944, s. 682-742.

GİRAUD, Rene, “Göktürk İmparatorluğu İlteriş, Kapgan ve Bilge'nin Hükümdarlıkları”, (çev. İsmail Mangaltepe), CBÜ Sosyal Bilimler Dergisi, C.9, S. 2, Manisa 2011, s. 729-736.

GÖMEÇ, Saadettin, "Kök Türkçe Yazıtlarda Geçen Göller ve Nehirler", Tarih Araştırmaları Dergisi, C. XXVII, S. 44, Ankara 2008, s. 1-20.

GÜNAY, Ünver- Harun Güngör, Türklerin Dini Tarihi, Rağbet Yayınları, İstanbul 2007.

KAFESOĞLU, İbrahim, Eski Türk Dini, Kültür Bakanlığı Yayınları, Ankara 1980.

KAFESOĞLU, İbrahim, Türk Milli Kültürü, Ötüken Yayınevi, İstanbul 2015.

KÖSE, Onur, "Türk Kültüründe Dağ ve Düzgün Baba Dağı", Genel Türk Tarihi Araştırmaları Dergisi (GTTAD), C. 1, S. 1, (Ocak 2019), s. 13-24.

MAHMUD, Kaşgarlı, Divanû Lügat-it-Türk, C.1, (çev. Besim Atalay), TDK Yayınları, Ankara 2006.

Moğolların Gizli Tarihi, çev. Ahmet Temir TEMİR, TTK, Ankara 2016.

ÖGEL, Bahaeddin, "Doğu Göktürkleri Hakkında Vesikalar Ve Notlar", Belleten, C. XXI. , S. 81, Ankara 1957, s. 81-137.

ÖGEL, Bahaeddin, “ilk Töles Boyları", Belleten, C. XII, S. 48, Ankara 1948, s. 811-826.

ÖGEL, Bahaeddin, Türk Mitolojisi II, Milli Eğitim Basımevi, İstanbul 1971.

ÖGEL, Bahaeddin, Türk Mitolojisi, MEB Yayınları, C. 1, İstanbul 1993.

ÖZTÜRK, Ali, Ötüken Türk Kitabeleri, Ötüken Yayınevi, Ankara 1973.

POLO, Marco, Marco Polo Seyahatnamesi, Tercüman 1001 Temel Eser, C. 2, İstanbul 1990. 
ROUX, J. Paul, Moğol İmparatorluğu Tarihi, (çev. Aykut Kazancigil), Kabalc1 Yayınevi, İstanbul 2001.

ROUX, J. Paul, Orta Asya Tarih Ve Uygarlık, (çev. Lale Arslan), Kabalcı Yayınevi, İstanbul 2006.

ROUX, J. Paul, Türklerin ve Moğolların Eski Dini, (çev. Aykut Kazancıgil), Kabalcı Yayınevi, İstanbul 2002.

SCHMIDT, P. Wilhelm, "Eski Türklerin Dini”, İÜEF Türk Dili ve Edebiyatı Dergisi, C. 13, S. 0, İstanbul 1964, s. 75-90.

TAŞAĞIL, Ahmet, Gök-Türkler I-II-III, TTK, Ankara 2018.

TÜRKER, Özgür, Nefesten Taşa, Taştan Kağıda: Türkler ve Moğollarda Tarih Yazıcılı̆̆ı, Türkiye Âlim Kitapları, Saarbrücken 2014.

\section{EKLER}

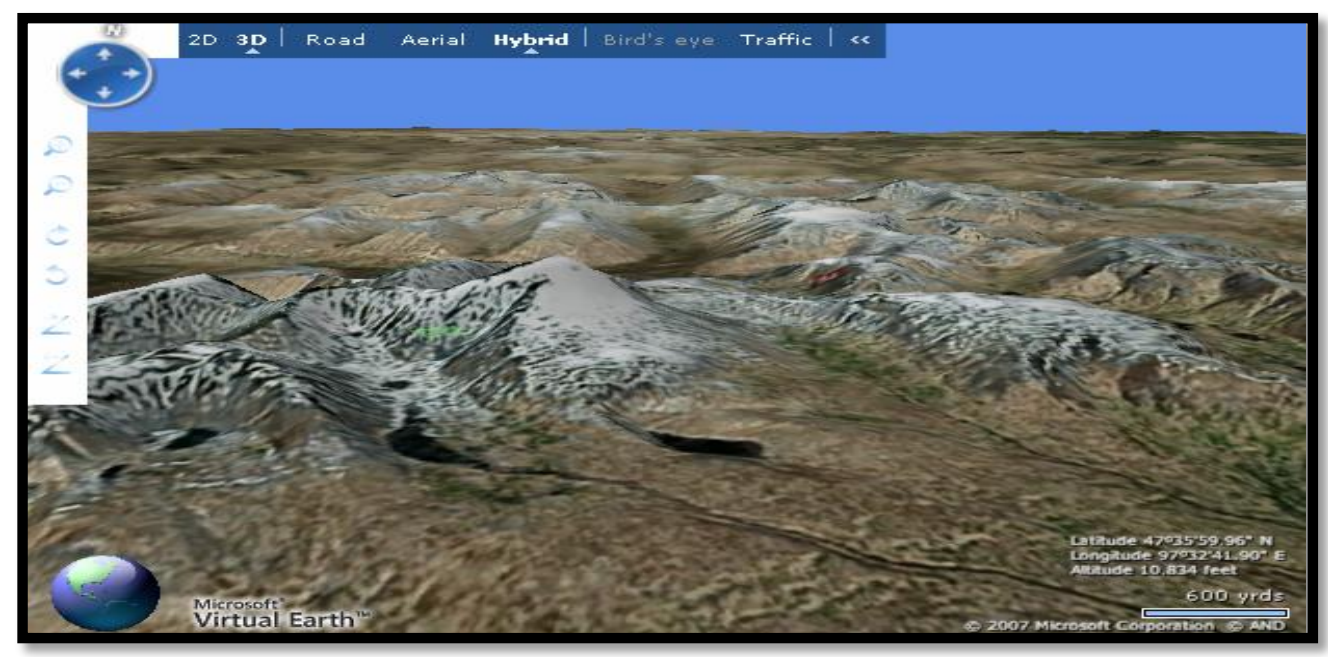

Resim 1: Otgon Tenger'in uydu fotoğrafi (Erhan, Aydın, a.g.m., s. 1269.)

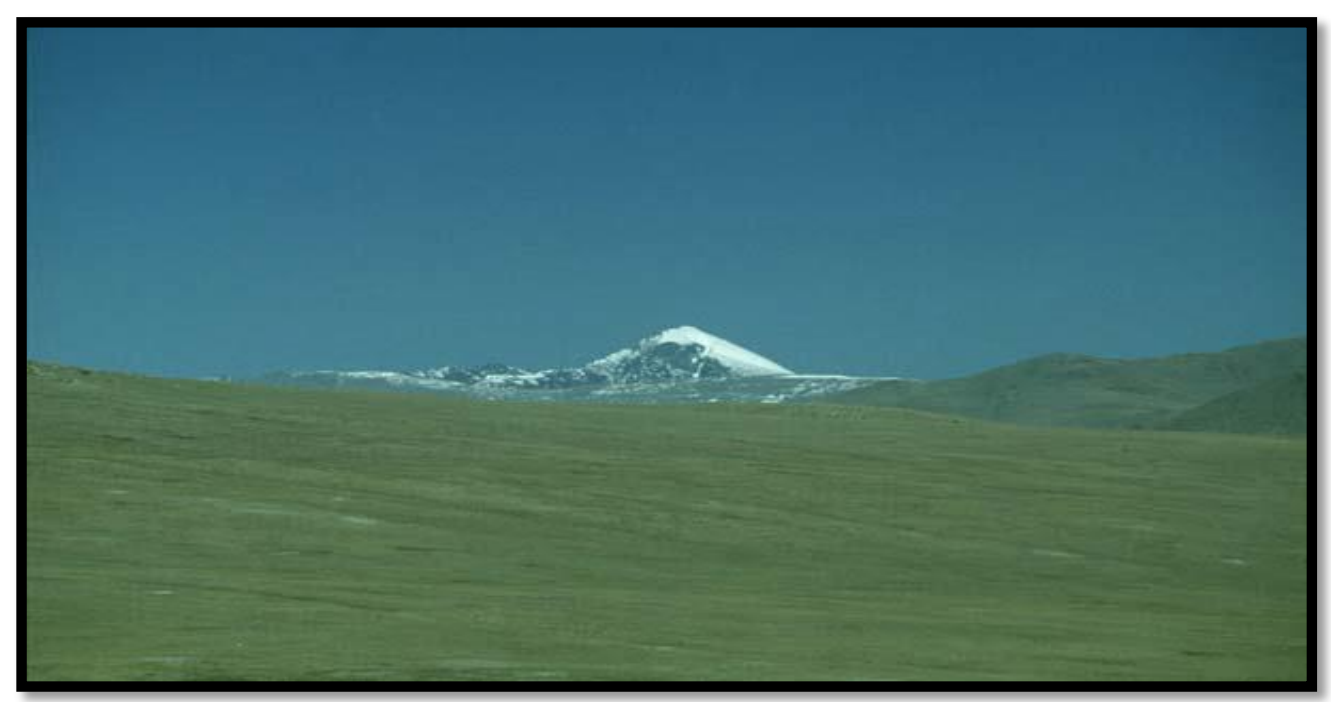

Resim 2: Otgon Tenger dağı (Erhan, Aydın, a.g.m. , s. 1269.)

\section{ULUSLARARASI EĞİTIM VE TARIH ARAŞTIRMALARI DERGİSI}

(ETA JOURNAL)

INTERNATIONAL JOURNAL OF EDUCATION AND HISTORY RESEARCH

Yıl: 1, Sayı: 1, Aralık 2019, s.40-51. 


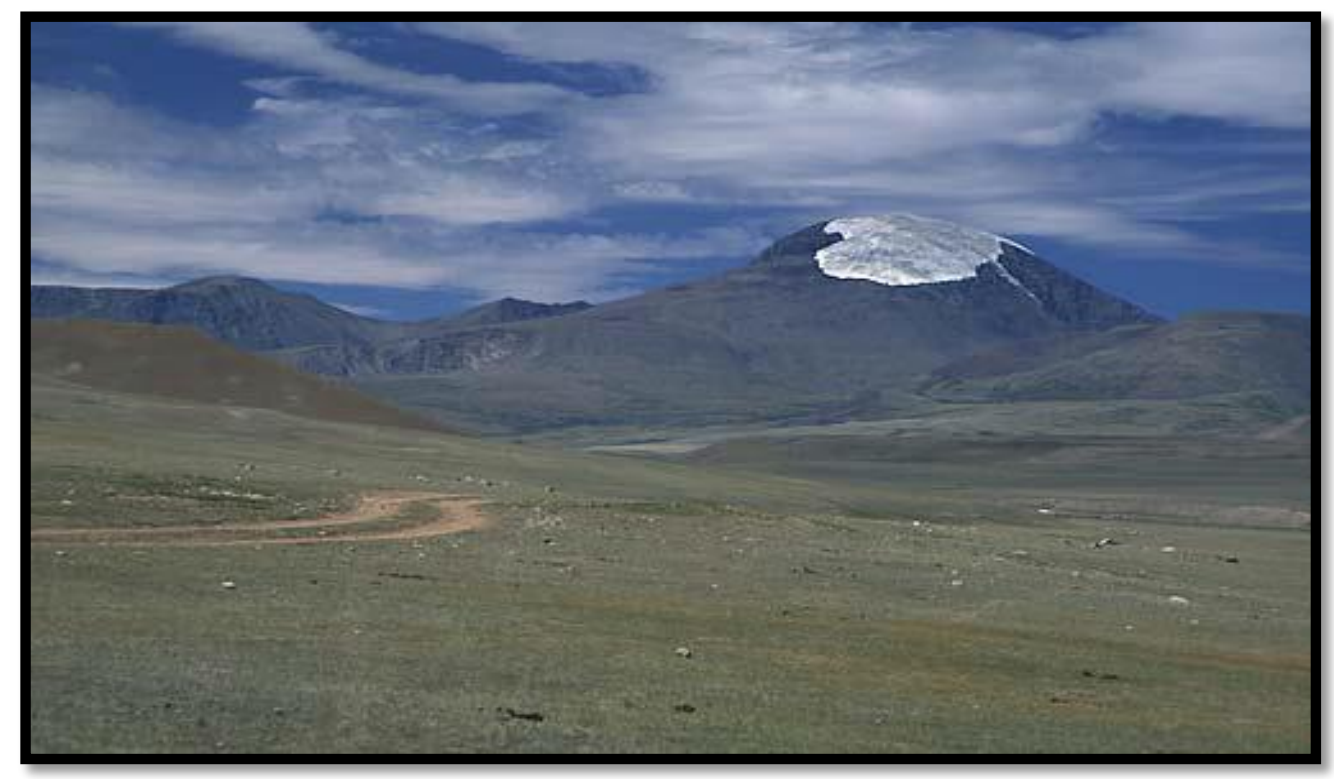

Resim 3: Otgon Tenger dağı (Erhan, Aydın, a.g.m. , s. 1270.)

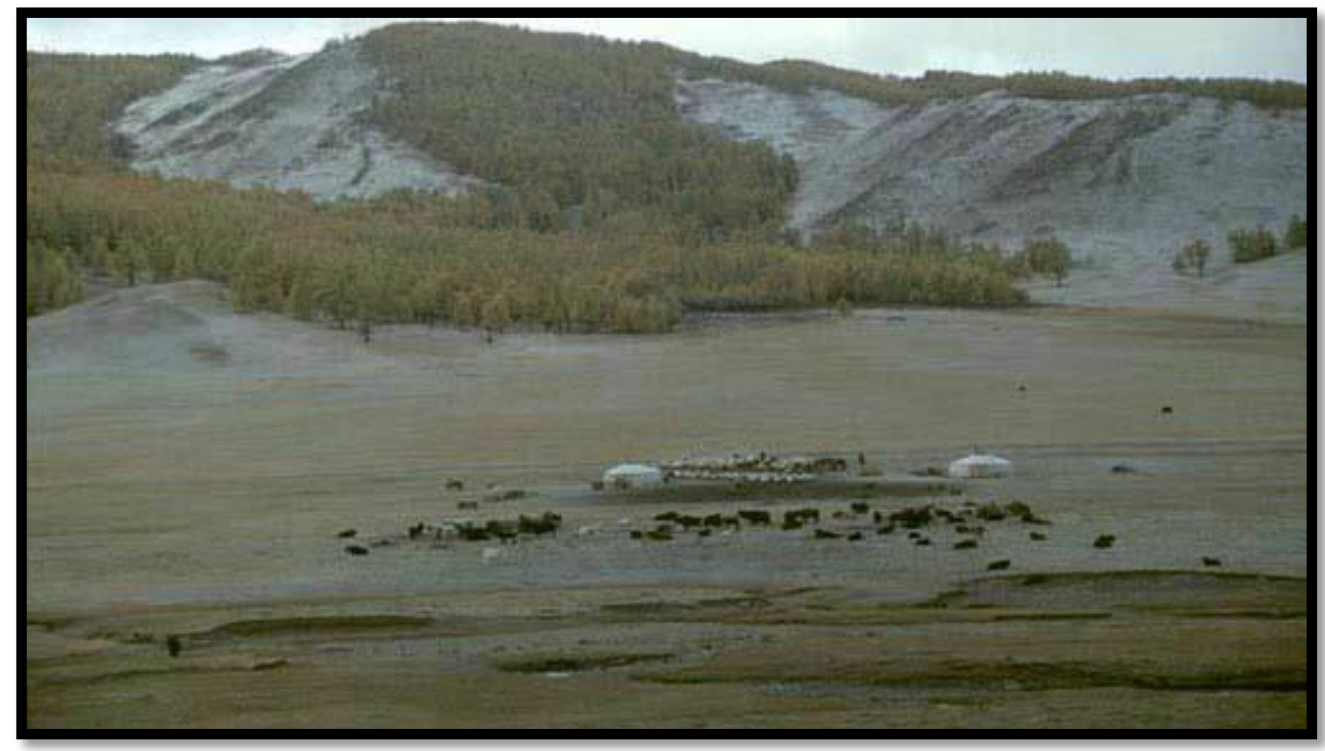

Resim 4: Otgon Tenger dağı civarında ormanlı dağlar (Erhan, Aydın, a.g.m. , s. 1270.) 
ULUSLARARASI EĞITTIM VE TARIH ARAŞTIRMALARI DERGİSI (ETA JOURNAL)

INTERNATIONAL JOURNAL OF EDUCATION AND HISTORY RESEARCH Yıl: 1, Sayı: 1, Aralık 2019, S.40-51. 